\title{
A estilística da literatura indígena brasileira: a alteridade como crítica do presente - sobre a noção de eu-nós lírico-político
}

\author{
The Stylistics of Brazilian Indian literature: \\ the alterity as critic of the present - on the \\ concept of lyrical-political I-We
}

\author{
Leno Francisco Danner ${ }^{*}$ Julie Dorrico ${ }^{* *}$, Fernando Danner ${ }^{* * *}$
}

\begin{abstract}
RESUMO
Defendemos, nesse artigo, que a literatura indígena brasileira contemporânea possui como núcleo epistemológico-político e como estilo estético-literário o ativismo e a militância público-políticos diretos e pungentes, em sua ligação umbilical e em sua dependência profunda relativamente ao Movimento Indígena. Nesse sentido, a literatura indígena brasileira apresenta três marcas distintivas e constitutivas que lhe dinamizam nessa sua vinculação seja ao Movimento Indígena, seja em termos de esfera público-política e como práxis estética, política e normativa, a saber: (a) parte da afirmação da memória ancestral e comunitária, da autoexpressão desde a singularidade antropológica do próprio indígena; (b) com base nisso, explicita, denuncia e enfrenta pública e politicamente a condição de exclusão, de marginalização e de violência vividas e sofridas; e (c), como síntese de tudo isso, assume um sentido político-politizante, carnal e vinculado que se expressa por meio de uma voz-práxis estético-literária que funda o eu-nós lírico-político ativista, militante e engajado, comprometido diretamente com a causa indígena. Assim, argumentamos que o núcleo normativo da literatura indígena brasileira contemporânea consiste na intersecção de comunidade e indivíduo, no mútuo sustento de afirmação e atualização da memória ancestral-comunitária como singularidade antropológica, de denúncia da violência sofrida como minoria e de crítica do presente do e por parte do eu-nós lírico-político indígena. Essa é a linguagem, o estilo e a práxis da literatura indígena brasileira hodierna que marcam, dinamizam e definem as produções estético-literárias indígenas e a postura de seus/as intelectuais, bem como do próprio Movimento Indígena de um modo mais geral.
\end{abstract}

Palavras-Chave: Literatura Indígena; Alteridade; Crítica do Presente.

\footnotetext{
* Universidade Federal de Rondônia (UNIR).

** Pontifícia Universidade Católica do Rio Grande do Sul (PUCRS).

*** Universidade Federal de Rondônia (UNIR).
} 


\section{ABSTRACT}

We defend in this paper that contemporary Brazilian Indian literature has as its epistemological-political core and aesthetical-literary style the direct and pungent public-political activism and militancy, in its intrinsic linking and profound dependence relatively to the Indian Movement. In this sense, Brazilian Indian literature has three distinctive and constitutive characteristics which streamline it in its linking to both the Indian Movement and the public-political sphere, and as aesthetical, political and normative praxis, namely: (a) it starts from the affirmation of the ancestral and communitarian memory, from the self-expression based on the Indian anthropological singularity; (b) from here, it makes explicit, denounces and faces publicly and politically the condition of exclusion, marginalization and violence lived and suffered by Indians; and (c), in resume, it assumes a political-politicizing, carnal and linked sense which is expressed by means of an aesthetical-literary voice-praxis that grounds the activist, militant and engaged lyrical-political I-We, directly compromised to the Indian cause. So, we argue that the normative core of the contemporary Brazilian Indian literature consists in the intersection of community and individual, in the mutual support of affirmation and renewal of ancestral-communitarian memory as anthropological singularity, of denouncement of the suffered violence as a minority and of criticism of the present by the lyrical-political I-We. This is the language, the style and the praxis of the current Brazilian Indian literature that characterize, streamline and define the Indian aesthetical-literary productions and the public posture of its intellectuals, as well as of the Indian Movement in general.

Key-Words: Indian Literature; Alterity; Critic of the Present. 
DANNER, L. F.;

DORRICO, J.;

DANNER, F.

A estilística

da literatura

indígena

brasileira: a

alteridade

como crítica do

presente - sobre a

noção de eu-nós

lírico-político
Eu acho que teve uma descoberta do Brasil pelos brancos em 1500, e depois uma descoberta do Brasil pelos índios na década de 1970 e 1980. A que está valendo é a última. Os índios descobriram que, apesar de eles serem simbolicamente os donos do Brasil, eles não têm lugar nenhum para viver nesse país. Terão de fazer esse lugar existir dia a dia. Não é uma conquista pronta e feita. Vão ter de fazer isso dia a dia, e fazer isso expressando sua visão do mundo, sua potência como seres

humanos, sua pluralidade, sua vontade de ser e viver (Krenak, 2015, p. 248).

\section{Considerações iniciais}

Nesse artigo, argumentamos que a literatura indígena brasileira contemporânea é marcada, constituída e dinamizada por uma voz-práxis estético-literária que, sob a forma de um eu-nóslírico-político, parte da afirmaçãoedaautoexpressão desdesuasingularidade antropológica, afirmando e atualizando sua memória ancestral-comunitária e, a partir dela, realizando uma práxis público-política de crítica do presente, de resistência cultural e de luta política em que o desvelamento e o enfrentamento da exclusão, da marginalização e da violência vividas e sofridas definem uma postura de ativismo, de militância e de engajamento dos/as escritores/as indígenas seja para com o Movimento Indígena, de cunho político-cultural, seja em termos de esfera pública, no que se refere à construção de hegemonia cultural, normativa, política e epistêmica ${ }^{1}$. Nesse sentido, a literatura indígena, enquanto uma práxis política-politizante, vinculada e carnal, e sob a forma de ativismo, de militância e de engajamento no Movimento Indígena, permite

1 Por Movimento Indígena Brasileiro, os/as intelectuais indígenas querem significar a organização e a união dos povos indígenas e a atuação público-política de suas lideranças em favor de suas comunidades/ etnias enquanto evento que emergiu a partir da década de 1970 em diante, com especial ênfase nas décadas de 1980 e de 1990, em que se consolidou e se expandiu. Esse movimento possuía e possui uma organização pan-indígena constituída e dinamizada em torno de uma agenda político-programática e de interesses comuns, com estratégias e práticas utilizadas pelas comunidades indígenas em defesa de seus interesses, de

Revista Letras, seus direitos e como resistência contra a violência vivida e sofrida (cf.: Baniwa, 2006; Krenak, 2015).
Curitiba, UFPR,

n. 97 , pp. 143-166,

jan./jun. 2018.

ISSN 2236-0999

(versão eletrônica) 
a superação do silenciamento e do confinamento dos povos indígenas à esfera privada de vida, à aldeia pura e simplesmente, um silenciamento e um confinamento apolíticos e despolitizadores que lhes foram impostos pela cultura majoritária e em termos tecnocráticos, em uma postura e em um movimento que lhes permitem superar esse silenciamento e esse privatismo exatamente por meio e sob a forma desse ativismo, dessa militância e desse engajamento como sujeitos público-políticos.

Para desenvolvermos esse argumento, dividimos o texto em dois capítulos que, de todo modo, estão imbricados, sendo mutuamente dependentes. No primeiro, mais geral, definimos a condição de minoria como um conceito e uma questão políticos, como uma construção política no duplo sentido do termo, isto é, (a) como conceito simbólico-normativo e como produto de processos materiais de exclusão, de unidimensionalização e de violência, por um lado; e (b) como expressão e publicização da própria condição de e como minoria, por outro. Se, no primeiro caso, as minorias são construções de maiorias socioculturais hegemônicas, no segundo, a própria voz-práxis dessas mesmas minorias, sempre que é publicizada, assume um sentido e uma atuação irremediavelmente políticas e politizantes. Ora, em consequência disso, argumentamos que a voz-práxis das minorias é sempre e diretamente carnal, vinculada e política-politizante, o que aponta para o fato de que ela é autoexpressão de um grupo sociocultural estigmatizado, periferizado, silenciado e violentado por causa de sua singularidade antropológica, o que significa que a vinculação público-política do/a escritor/a de minorias parte sempre dessa pertença, dessa dependência e dessa publicização radicais e pungentes desse mesmo grupo, de sua condição de marginalização, de exclusão e de violência, utilizando-a como base para a crítica social, a resistência cultural e a luta política. É por isso, aliás, que as minorias são, em sua voz-práxis pública e publicizada, fundamentalmente políticas e politizantes, uma vez que confrontam, no simples fato de serem, de aparecerem e de se manifestarem como minorias, os processos apolíticos, despolitizados, naturalizados e a-históricos de unidimensionalização, de massificação e de totalização sustentados e realizados por grupos socioculturais majoritários - a literatura de minorias, portanto, como direta e pungentemente política e politizante, ativista, militante e engajada. A partir disso, elaboramos o segundo capítulo tendo por base a análise de escritores/as indígenas brasileiros/ as hodiernos, com o intuito de mostrar o quanto sua produção estético-literária assume esse sentido ativista, militante e engajado em termos público-políticos e relativamente ao Movimento Indígena. Isso significa, como procuraremos reconstruir e defender na segunda parte, que a literatura indígena se vincula direta e pungentemente ao Movimento Indígena, tendo na afirmação e na atualização da memória, sob a forma de assunção e de promoção da tradição ancestral, comunitária e xamânica e de crítica do presente, de denúncia da marginalização vivida e sofrida, o núcleo normativo de sua constituição e o cerne de sua vinculação público-política. Com isso, imbricando-se profundamente ao Movimento Indígena e assumindo-se como ativismo, militância e engajamento, a literatura indígena permite a superação do silenciamento e do confinamento à esfera privada, apolítica, não-pública a que 
DANNER, L. F.;

DORRICO, J.;

DANNER, F.

A estilística

da literatura indigena

brasileira: $a$

alteridade

como crítica do

presente - sobre a

noção de eu-nós

lírico-político
Revista Letras,

Curitiba, UfPR,

n. 97 , pp. 143-166,

jan./jun. 2018.

ISSN 2236-0999

(versão eletrônica) esses mesmos povos indígenas foram e são relegados pela cultura majoritária e em termos tecnocráticos. Nesse sentido, ela guarda uma relação estreita e mutuamente dependente com a política, tornando-se, em verdade, direta e pungentemente práxis política, normativa, estética ativista, militante e engajada.

Queremos, antes de tudo, realizar uma delimitação conceitual, ainda que um tanto genérica e aberta para o momento, do termo voz-práxis, que utilizamos ao longo do texto. Em sua acepção matricial, construída por Karl Marx, e, por exemplo, utilizada e reestilizada, hodiernamente, por Jürgen Habermas e por Paulo Freire, o conceito significava-significa a umbilical correlação e dependência entre teoria e prática, seja no sentido de dar-se cientificidade à ação política cotidiana (e politicidade à prática científica institucionalizada), seja, para o que nos interessa aqui, de tornar essa ação reflexiva, dotada de organização, de projeto e de orientação, inclusiva e participativa. A práxis, portanto, enfatiza uma perspectiva ativa, participativa e reflexiva, apontando para essa ligação entre teoria e prática de que falamos, núcleo duro da teoria social crítica, para a qual a reflexividade depende de uma ação direta dos excluídos mediada e perpassada por fundamentação teórica - a transformação social via ação política que se escora em um diagnóstico e em uma fundamentação científicos. A práxis, enquanto ação reflexiva, envolve, por conseguinte, a interrelação entre os grupos oprimidos (o proletariado, as minorias, os movimentos sociais) e uma perspectiva científica de mundo, e aponta para o fato de que os próprios oprimidos, não mais como massa de manobra, mas como sujeitos na plenitude de sua formação intelectual, assumem o protagonismo sobre e acerca de sua própria condição e, como consequência, da situação social que lhes produz e que somente eles - e não os opressores - podem modificar. Por isso, retomando Karl Marx, Jürgen Habermas e Paulo Freire, a teoria social crítica deve fazer-se práxis política inclusiva, participativa e direta, dando a própria palavra e a própria oportunidade de os oprimidos - não-sujeitos de sua própria condição - tornarem-se sujeitos autoconscientes, emancipados e emancipatórios (cf.: Marx, 1989, pp. 03-39; Marx \& Engels, 2001, pp. 99-103; Habermas, 1987, pp. 14-15, pp. 47-48; Freire, 1987, pp. 16-32).

Note-se, aqui, que essa perspectiva exige ativismo, militância e engajamento a partir da condição sociopolítica ou étnico-antropológica que se vive, uma postura que não pode ser mediada ou realizada apenas por meio da torre de marfim da teoria. Baseados nessa descrição genérica, compreendemos e utilizamos o conceito de voz-práxis querendo significar, com ele, o fato de que os/as escritores/ e os/as intelectuais indígenas utilizam-se de sua palavra, calcada na sua tradição ancestral-comunitária, como fundamento de uma atitude público-política reflexiva, ativista e militante que busca exatamente a publicização e a politização da condição, da situação e da causa desses povos indígenas. Nesse diapasão, a literatura indígena permite a autoexpressão direta, sem mediações institucionalistas, cientificistas e tecnicistas dos povos indígenas por si mesmos e a partir de si mesmos, lhes possibilitando a autoafirmação via retomada dessa tradição ancestral-comunitária e, a partir disso, a realização de uma postura de crítica do presente. Essa expressão 
direta assume um sentido catártico, de remodelação e de reavaliação de todo o peso do colonialismo, de toda a pungência da violência colonial, acumulada em cinco séculos de contato etnocida, buscando inserir-se na dinâmica constitutiva de nossa sociedade, em todas as suas esferas, começando pela política, passando pela cultura, pela religião e pela educação e chegando-se à própria economia. É assim, portanto, que a literatura indígena, enquanto palavra direta e singular, ao assumir esse sentido catártico, leva à reflexividade do indígena por si mesmo em um triplo sentido: permite, dada sua abertura paradigmática, autoexpressão e autoafirmação desde sua condição; o leva a publicizar e politizar sua condição de marginalização, de exclusão e de violência, de modo que, por meio da própria autoexpressão direta e singular, ele supera o silenciamento, a invisibilização e o privatismo público-políticos aos quais ele tradicionalmente esteve e está submetido em termos de esfera pública, política e cultural; e, além disso, lhe permite divulgar e promover socialmente a riqueza de sua pertença, de sua singularidade, na multiplicidade das vozes, das práticas e dos valores construídos milenarmente pelos povos indígenas. A literatura indígena (assim como a literatura de minorias de um modo mais geral), em termos de ativismo, militância e engajamento do eu-nós lírico-político, se torna voz como práxis, práxis como voz, ou seja, voz-práxis, palavra reflexiva porque singular, palavra ativista e ativismo pela palavra, via participação e inclusão de uma singularidade que denuncia a condição de exclusão, de marginalização e de violência; ação crítica e emancipatória pela palavra dita em primeira pessoa, de modo reflexivo e catártico - os cinco séculos de colonização etnocida e de deslegitimação normativa, entalados na garganta, podem, aqui, por meio desse engajamento como palavra direta da própria diferença por si mesma e desde si mesma, ser contados, compartilhados publicamente.

Voz-práxis, portanto, alude à publicização da própria fala, da própria voz como uma postura político-cultural marcada pela e dinamizadora da reflexividade dos povos indígenas, propiciando-lhes superar seu silenciamento, sua invisibilização e sua exclusão e consolidar-se na esfera pública como sujeitos político-culturais. A voz, como ação refletida e reflexiva, promove a autoexpressão e a autoafirmação e, com isso, permite ao/à indígena a crítica pungente de sua condição em nossa sociedade. Com isso, ela, a voz refletida e reflexiva, leva à profunda intersecção da literatura com o Movimento Indígena, contribuindo para a propagação de seus ideais, para a legitimação de sua presença público-política, para a hegemonia de seus valores e para a busca do diálogo intercultural. Sobretudo, a voz-práxis indígena, enquanto característica central da literatura indígena brasileira, assume-se como perspectiva crítica, criativa e reflexiva, porque dita e dinamizada de modo direto, sem mediações, de modo que uma minoria - ou qualquer minoria - pode expressar-se a partir de sua condição, de sua singularidade e, ao fazer isso, politizar-se e politizar a sociedade em que está situada. É uma voz reflexiva, uma práxis emancipatória, posto que política e politizante, para si e para a sociedade na qual está inserida e que produziu e reproduz, na maior parte das vezes de modo apolítico e despolitizado, essa condição de minoria. 
DANNER, L. F;

DORRICO, J.;

DANNER, F.

A estilística

da literatura indigena

brasileira: $a$

alteridade

como crítica do

presente - sobre a

noção de eu-nós

lírico-político

\section{A voz-práxis estético-política das minorias como ativismo e militância}

A voz-práxis das minorias é irremediavelmente política, ativista e militante, o que significa que sua expressão como minorias assume um sentido diretamente politizante, carnal e vinculado, comprometido com a própria situação e com a própria singularidade da autora, do autor, do grupo em questão. Nesse sentido, três características fundamentais definem a estrutura, o estilo e a vinculação da voz-práxis estético-literária das minorias enquanto crítica do presente, como ativismo, militância e politização profundos e abrangentes, a saber: (a) ela de antemão é política e politizante, porque as minorais são uma construção simbólica e material dinamizada por processos de silenciamento, de exclusão, de marginalização e de destruição teórico-práticos levados a efeito por maiorias; (b) ela somente pode constituir-se e dinamizar-se como crítica do presente por meio da afirmação da própria condição de minorias, partindo de seu horizonte antropológico-ontológico, de suas experiências socioculturais e de suas bases epistemológico-políticas, e publicizando suas experiências de dor, de negação e de violência sofridas e vividas como minorias, pelo fato de serem minorias - a voz-práxis estético-literária das minorais como um movimento que vai da autoafirmação identitária à crítica do presente; (c) ela é caracterizada pela intrínseca e umbilical ligação entre eu e grupo, indivíduo e comunidade, de modo a dar origem a isso que chamamos de eu-nós lírico-político, em que o autor e a autora estão profundamente comprometidos e conectados à comunidade de origem, falando em nome dela e por ela, o que leva à constituição diretamente política, militante e ativista da voz-práxis estético-literária das minorias e, no caso, do autor e da autora pertencentes às minorias, posto que sua voz-práxis tem por base sempre essa condição, essas experiências e essa publicização como minorias (Dalcastagnè, 2012; Thiél, 2004; Almeida, 2009; Almeida \& Queiroz, 2004; Danner \& Dorrico Peres, 2017).

Reflitamos sobre esses três pontos. Com efeito, o primeiro aspecto importante para considerarmos a extensa e cada vez mais pungente produção estético-literária das minorias - mulheres, negros/as, índios/as, LGBTTs etc. - está no reconhecimento de que o conceito de minoria possui um significado diretamente político, posto que as minorias são uma construção simbólico-material de grupos socioculturais hegemônicos localizados no espaço e no tempo (muitas vezes conquistando hegemonia por meio da destruição da alteridade), e não um produto natural e/ou uma imposição divina de cunho não-normativo, a-histórico, apolítico e despolitizado. Por construção simbólico-material, entendemos o fato de que esses grupos socioculturais hegemônicos produziram histórica e politicamente todo um arcabouço normativo essencialista e naturalizado, unidimensional e totalizante acerca de si e da alteridade e, a partir dele, realizaram processos de exclusão, segregação e destruição material contra as diferenças, tanto no sentido de homogeneizá-las e unidimensionalizá-las quanto com o escopo de eliminá-las de uma vez por todas da face da Terra (Spivak, 2010; Fanon, 1968; Habermas, 2002). As diferenças, as alteridades, portanto, são uma construção política enormativa e sua condição material como minorias (isto é, não apenas como grupos marginalizados e excluídos, mas também como numericamente minoritários por causa do genocídio-extermínio a que
Revista Letras,

Curitiba, UFPR, n. 97 , pp. 143-166, jan./jun. 2018. ISSN 2236-0999 (versão eletrônica) 
foram submetidos) se deve a processos de destruição material fundamentados naquele arcabouço político-normativo assumido e utilizado por grupos majoritários. Este é o caso das mulheres frente aos homens na tradição judaico-cristã, dos grupos LGBTTs frente mais uma vez a essa tradição judaico-cristã essencialista e naturalizada em termos de gênero e de sexualidade, dos/as índios/as e dos/as negros/as frente ao modelo antropológico racionalista eurocêntrico etc. Aqui, a mulher, o/a homossexual, o/a negro/a e o/a índio/a gradativamente assumiram um sentido decaído, negativo, por parte dessa tradição religioso-cultural, o que também significa que a eles e a elas foram impostos processos de deslegitimação, de exclusão e de silenciamento políticos, que construíram esse sentido normativa e politicamente negativo por trás do conceito de minoria, consolidando uma cultura cotidiana que naturalizou tais processos de exclusão e essas mesmas minorias ao ponto de silenciá-las, de remetê-las como que exclusivamente ao âmbito privado da vida, retirando-as da esfera pública e como sujeitos, práticas e valores políticos e politizantes, legitimamente públicos. Nesse sentido, o conceito de minoria passa a assumir um significado política e moralmente negativo, como algo e alguém que não apenas destoam profundamente da normalidade cotidiana, senão que também a põem em xeque, destruindo sua estabilidade, imutabilidade, naturalidade e dignidade - por isso, essas mesmas minorias, ao politizarem, historicizarem e profanizarem esse padrão normal totalizante, a-histórico, essencialista e naturalizado, apolítico e despolitizado, são vistas como o grande inimigo a ser silenciado, excluído, marginalizado e, se necessário, destruído praticamente.

Assim, enquanto construção política e normativamente referendada, as minorias aparecem de antemão, em termos de voz-práxis, com um estigma estampado em seus corpos, em suas culturas, em suas formas de ser e de estar no mundo, em suas perspectivas antropológicas e epistemológicas. E, nesse caso, a simples percepção de que se trata de um indivíduo pertencente a um grupo sociocultural decaído, de uma minoria em sentido normativamente negativo, basta para anular qualquer possibilidade de contato paritário, de respeito e de consideração recíprocos, de igual tratamento intersubjetivo, de acolhimento e de proteção institucionais. Assim é que tradicionalmente as minorias ou foram destruídas em praça pública como exemplo a todos aqueles que quisessem e pudessem romper com certo padrão de normalidade calcado em bases essencialistas e naturalizadas, ou foram reduzidas e empurradas como que totalmente à esfera privada da vida, perdendo sua politicidade, tendo silenciada essa sua politicidade, como se o ser e o viver mulher, homossexual, indígena e negro/a somente pudessem manter uma legitimidade mínima longe dos olhos do público, da esfera público-política, tendo certa legitimidade apenas se perdessem sua politização, isto é, caso se assumissem como algo totalmente privado, íntimo, não-público e apolítico. Aliás, esse ponto, como podemos perceber, é ainda hoje uma tônica de nossa sociedade brasileira, a saber, as diferenças até podem ser possíveis e legítimas, mas não como sujeitos, práticas e valores público-políticos que possam estar visíveis à luz do dia e por todos e todas, para todos e todas, que possam questionar politicamente e relativizar normativamente padrões normalizadores, essencialistas e naturalizados em sua apoliticidade-despolitização e a-historicidade cotidianas, o que significa que, se elas quiserem ser protegidas e respeitadas, necessitam 
DANNER, L. F.;

DORRICO, J.;

DANNER, F.

A estilística

da literatura indígena

brasileira: a

alteridade

como crítica do

presente - sobre a

noção de eu-nós

lírico-político
Revista Letras,

Curitiba, UfPR,

n. 97 , pp. 143-166,

jan./jun. 2018.

ISSN 2236-0999

(versão eletrônica) esconder-se na esfera do seu quarto, da sua casa, da sua intimidade, um âmbito totalmente ausente e destituído de publicidade (cf.: Krenak, 2015; Danner, Bavaresco \& Danner, 2017). $\mathrm{Na}$ esfera pública, as diferenças não são possíveis e nem legítimas, devendo, caso queiram assumir essa atuação e essa visibilidade público-políticas, ser deslegitimadas, combatidas e silenciadas, posto que põem por terra a normalidade essencialista e naturalizada própria às maiorias, aquele tipo de verdade e de valor que somente é possível por meio da uniformização, da unidimensionalização e da totalização estritas, que se assumem como apolíticas e que, portanto, despolitizam as diferenças e as contradições exatamente por meio do silenciamento, da exclusão, da marginalização e da violência. Com isso, tanto os conceitos de povo e de nação quanto o consequente conceito de esfera público-política assumem claramente um sentido unidimensional e totalizante, massificado, tornando-se, em muitas situações, castradores e negadores das diferenças, em que a heterossexualidade, a cor branca e a razão impessoal, todas baseadas em uma ordem apolítica e despolitizada, são as métricas fundamentais para a legitimação da práxis - novamente, aqui, as diferenças são empurradas para a esfera da vida privada, para a intimidade, de cunho apolítico, não-normativo e despolitizado, sendo profundamente silenciadas.

Nesse sentido, como estamos argumentando, a autoexpressão e a autoafirmação estético-literária das minorias são ab origine políticas e politizantes, carnais e vinculadas, ativistas e militantes. Em primeiro lugar, enquanto condição e construção políticas, a visibilização das minorias assume em cheio esse sentido político e politizante por si (e para si) e para os outros. A voz-práxis estético-literária das minorias é política e politizante por si e para si, uma vez que o autor e a autora expressam-se por meio de estilos, práticas, rituais e valores próprios ao grupo de que fazem parte - aliás, a cor da pele, a estrutura antropológico-cultural, a expressão corporal e a postura em termos de gênero e de sexualidade de antemão aparecem como representando e pertencendo a uma minoria, o que significa que a enunciação estético-literária das minorias já não pode esconder-se, ser silenciada (e calar-se) e negada (e negar-se) nessa sua pertença, nessa sua dinâmica (como minoria). Aqui, o autor e a autora são pertencentes ao grupo sociocultural em questão: mulher, negro e negra, indígena, homossexual - às vezes possuindo mais do que um único desses qualificativos. Ele e ela são, assim, autor/a negro/a, indígena, homossexual etc., não podendo silenciar sobre, apagar, esconder ou até negar essa pertença antropológico-cultural, nem essa estilística epistemológica (de pertença a uma minoria, de manifestação como minoria) e nem a profunda militância de que sua voz-práxis se reveste e se constitui. E a voz-práxis estético-literária das minorias, uma vez que direciona-se à esfera público-política, saindo da esfera privada, apolítica e despolitizante e assumindo-se como publicidade, é política e politizante para os outros, uma vez que tanto confronta os padrões de normalidade majoritários e associados e sustentados pelas maiorias quanto é confrontada por essas mesmas maiorias por colocar em xeque as bases essencialistas e naturalizadas, apolíticas e a-históricas nas quais se sustenta a normalização, a unidimensionalização e a totalização em termos socioculturais, de gênero e de sexualidade, de economia e de política etc. As minorias, na esfera pública e como publicidade, ao substituírem o silenciamento e a apoliticidade da esfera privada pelo ativismo e pela militância como alteridades na esfera público-política, não apenas 
assumem-se como sujeitos, práticas e valores políticos e politizantes, mas também são enquadrados pelas maiorias como adversários políticos que desvelam a politicidade e a historicidade da negação, da exclusão, da marginalização e da violência, mostrando também que a suposta superioridade do branco, do macho, do heterossexualismo etc. não são dados naturais e nem podem ser respaldados teologicamente, senão que são pura e simplesmente construções, produtos-produções que possuem uma história e uma localização no espaço e no tempo, fruto da política e de relações políticas.

Ora, é nesse sentido que emerge o segundo significado fundamental da voz-práxis estético-literária das minorias, acima comentado, a saber, se as minorias são construções político-normativas e resultado de processos materiais (escorados nessas e dinamizados por essas construções político-normativas) de silenciamento, de exclusão, de marginalização e de destruição, então sua expressão só pode ser diretamente uma expressão política e politizante, em que o estilo, o sentido e a direção da voz-práxis estético-literária das minorias têm de assumir e utilizar-se do arcabouço antropológico-ontológico, sociocultural e epistemológico-político do grupo de que o autor e a autora fazem parte, explicitando, trabalhando e publicizando as experiências de ser e de estar no mundo, as práticas, os valores e os códigos constituintes tanto da vida do seu grupo quanto de suas experiências mais básicas como indivíduo pertencente a uma minoria e visto (e estigmatizado) como minoria. Do mesmo modo, como construção político-normativa e resultado de processos materiais de negação, de exclusão, de marginalização e de violência, a voz-práxis estético-literária das minorias, em superando e enfrentando o confinamento na esfera privada imposto a elas pelas maiorias e pelos padrões normalizadores da cultura e das instituições, necessariamente desvela, publiciza e compartilha intersubjetivamente essas experiências de dor, de negação e de violência a que são submetidas enquanto minorias, o que significa que seu silenciamento é substituído por uma atitude política-politizante, carnal e vinculada (Munduruku, 2004; Graúna, 2013; Potiguara, 2004; Kopenawa \& Albert, 2015; Krenak, 2015; Werá, 2016). Aqui, a autoexpressão das minorias e como minorias simplesmente não tem condições de negligenciar as situações de exclusão e de violência vividas e sofridas, ou de passar ao largo tanto da publicização quanto do enfrentamento delas: em sua manifestação estético-literária, essa autoexpressão das minorias já reflete e já apresenta-se como violentada, como produto de uma violência permanente e pungente cometida seja em termos simbólicos, normativos e políticos, seja em termos materiais e institucionais. Nesse sentido, a voz-práxis estético-literária das minorias baseia-se na e parte da sua constituição enquanto singularidade irredutível, dos valores, das práticas, dos códigos e dos ritos próprios à comunidade e ao grupo de que o autor e a autora fazem parte; ela também assume-se como publicização e explicitação das situações de marginalização, de exclusão e de violência, da dor e do sofrimento que a própria condição de minoria, enquanto construção política, carrega e representa; e, com isso, ela chega à e torna-se crítica do presente, desde a constituição de uma voz-práxis política-politizante, carnal e vinculada, em que o eu-nós lírico-político, profundamente ligado à comunidade e ao grupo de que faz parte, utiliza-se de suas 
DANNER, L. F.;

DORRICO, J.;

DANNER, F.

A estilística

da literatura indigena

brasileira: $a$

alteridade

como crítica do

presente - sobre a

noção de eu-nós

lírico-político
Revista Letras,

Curitiba, UfPR,

n. 97 , pp. 143-166,

jan./jun. 2018.

ISSN 2236-0999

(versão eletrônica) tradições e dessa sua vinculação, desvela e denuncia a violência sofrida e vivida e, em tudo isso, resiste culturalmente e luta politicamente, em uma atitude propositiva de autoafirmação e de enfrentamento das situações de exclusão e de marginalização às quais, como minoria, essa voz-práxis está submetida (Butler, 2003).

Com isso, chegamos ao terceiro ponto fundamental que é constituinte e dinamizador da voz-práxis estético-literária das minorias como perspectiva política-politizante, carnal evinculada que parte das bases antropológico-ontológicas, socioculturais e epistemológico-políticas próprias ao grupo em questão, uma voz-práxis que assume a crítica do presente como estilo e postura fundantes de sua manifestação como minoria e em termos de publicização e de enfrentamento das situações de marginalização, de exclusão e de violência sofridas e vividas, substituindo o silenciamento, a despolitização-apoliticidade e o confinamento à/na esfera privada por um profundo ativismo e militância em termos público-políticos. Esse ponto consiste na umbilical e intrínseca ligação entre eu e nós, autor/a e grupo, de modo a fundar-se um eu-nós lírico-político que, em sua manifestação público-política, aparece diretamente ligado ao e dependente do grupo sociocultural de que faz parte, militando politicamente com ele e a favor dele. Com efeito, a voz-práxis estético-literária das minorias e suas produções são fundamentalmente marcadas por um eu-nós lírico-político que, partindo da sua própria singularidade antropológica, dos valores, das práticas e dos ritos que ela comporta e apresenta, assume o desvelamento e o enfrentamento da exclusão, da marginalização e da violência sofridas e vividas como o leitmotiv dessa mesma voz-práxis, em uma atitude-postura de ativismo e de militância que é, como estamos argumentando, diretamente crítica do presente. O eu-nós lírico-político, portanto, é a marca, o estilo e a dinâmica epistemológico-políticos basilares para entender-se a construção estético-literária e a vinculação público-política dessas mesmas minorias em suas manifestações e produções, o que significa que tais manifestações e produções a voz-práxis das minorias - são caracterizadas e dinamizadas diretamente pela pertença ao grupo, pelos valores, pelas práticas, pelos ritos e pelas experiências vividas como grupo, como comunidade. E isso não poderia ser diferente: como estamos argumentando ao longo do texto, as minorias são ab origine políticas e politizantes, uma construção política, de modo que sua voz-práxis é direta e irremediavelmente política no duplo aspecto assumido e representado pelo conceito de minoria, a saber: a autoexpressão como minoria significa uma atitude de crítica, de contraposição, de resistência, de desconstrução e de enfrentamento da violência vivida e sofrida, do silenciamento, da exclusão e da marginalização impostos por grupos sócio-culturalmente hegemônicos e suas perspectivas de mundo totalizantes e unidimensionais; e, uma vez publicizada, uma vez rompendo com o silenciamento, o privatismo e a apoliticidade-despolitização a ela impostos pela cultura majoritária, a voz-práxis estético-literária das minorias questiona, sob a forma de eu-nós lírico-político, os padrões de normalização, as bases apolíticas-despolitizadas, a-históricas, essencialistas e naturalizadas nas quais se escora a marginalização (e o seu sentido e a sua condição como minorias), o que significa que também para os 
grupos hegemônicos essa voz-práxis é percebida como política e politizante, ainda que em um sentido negativo, como quebra e desvio da normalidade, como violação à ordem (apolítica, despolitizada, naturalizada) estabelecida.

Desse modo, a voz-práxis das minorias em termos estético-literários, constituída e dinamizada a partir de um eu-nós lírico-político que parte da comunidade e do grupo, passa pela crítica do presente enquanto desvelamento e enfrentamento da violência, da marginalização e da exclusão, transforma-se e assume-se diretamente como ativismo e militância, como uma perspectiva política-politizante, carnal e vinculada em que o autor/a está enraizado/a e umbilicalmente ligado/a tanto à singularidade antropológica do grupo e da pertença a esse grupo quanto às experiências comunitárias e grupais de exclusão, de violência, de negação e de destruição. Essa ligação entre eu e comunidade/ grupo, essa pertença fundamentalmente singular a uma alteridade irredutível, a uma minoria construída politicamente, juntamente com as experiências de silenciamento, dor e violência, são simplesmente inapagáveis, não podendo ser silenciadas, abandonadas ou sublimadas pelo autor/a de minorias, pelas produções estético-literárias das minorias. É por isso que a obra-práxis dali resultante é política-politizante, carnal e vinculada, ligada às experiências e comprometida com a causa da minoria em questão, o que significa que o/a autor/a pertencente às minorias não produz uma obra-práxis neutra, imparcial e impessoal no que diz respeito à questão dessa mesma vinculação, dessa mesma carnalidade. Diferentemente do escritor burguês, altamente individualista, que pode assumir-se como totalmente independente do grupo de que faz parte e que pode produzir uma obra basicamente descomprometida em relação a questões socioculturais, uma obra meramente formal, voyeurista, apolítica e despolitizada, de um indivíduo fechado em si mesmo e que, enquanto mônada, tanto basta-se a si mesmo quanto despreza ou sobrepõe-se à sociedade da qual faz parte, o/a escritor/a de minorias assume uma voz-postura-práxis ativista e militante, profundamente ligada à e dependente da singularidade antropológica e das experiências comunitárias e que, sob a forma de eu-nós lírico-político, torna-se direta e pungentemente crítica do presente. É uma voz-práxis ativista e militante que fala em nome da minoria e como minoria, que se utiliza de suas bases antropológicas e que desvela a sua condição como minoria, politizando sujeitos, valores, práticas e estruturas sociais, culturais e institucionais de exclusão, que geram, legitimam e reproduzem o silenciamento, a marginalização e a violência contra essas mesmas minorias. Esse é o caso, como veremos agora, das produções literárias indígenas deste nosso Brasil contemporâneo.

\section{A estilística da literatura indígena: o eu-nós lírico-político como crítica do presente}

Primeiramente, como destacam Daniel Munduruku, Graça Graúna, Maria Inês de Almeida e Sonia Queiroz, a grande marca da literatura indígena brasileira da atualidade consiste exatamente no fato de que o/a indígena passa a escrever por si mesmo, desde sua singularidade antropológica, passando por suas experiências 
DANNER, L. F.;

DORRICO, J.;

DANNER, F.

A estilística

da literatura indígena

brasileira: a

alteridade

como crítica do

presente - sobre a

noção de eu-nós

lírico-político
Revista Letras,

Curitiba, UfPR,

n. 97 , pp. 143-166,

jan./jun. 2018.

ISSN 2236-0999

(versão eletrônica) de silenciamento, de negação e de violência e chegando a uma postura de crítica do presente via voz-práxis estético-literária (cf.: Munduruku, 2004; Munduruku, 2016; Graúna, 2013; Almeida \& Queiroz, 2004). No dizer de Almeida \& Queiroz, “a literatura de autoria indígena revoga a presença do traço indígena na literatura nacional enquanto negatividade, desvio criativo, e se impõe afirmativamente, como presença positiva” (Almeida \& Queiroz, 2004, p. 220; os destaques são nossos). Nesse sentido, de mero personagem coadjuvante no grande drama da história nacional e branca, de participante marginal nos enredos amorosos e existenciais de personagens brancas, como representação extemporânea, caricata e idílica (e, ainda assim, marginal e coadjuvante nessa grande odisseia branca que é a nação brasileira), os/as indígenas, por meio da sua voz-práxis estético-literária, passaram a assumir protagonismo epistemológico e político, social e cultural em termos de crítica do presente. Com suas manifestações e produções estético-literárias, já não nos aparecem mais sob aquele modelo idílico e caricato do bom selvagem distante da civilização, como índio/a nobre e guerreiro/a, mas como cidadãos e cidadãs e como grupos socioculturais que não apenas se afirmam como parte da nação, senão que também lutam em prol de sua causa, sob a forma do Movimento Indígena a literatura indígena como aliada e promotora fundamental do Movimento Indígena brasileiro hodierno (cf.: Dorrico, 2017). Com isso, a literatura indígena assume-se como voz-práxis diretamente política e politizante, carnal e vinculada, ativista e militante nos três pontos discutidos no capítulo inicial deste texto, a saber: (a) em termos de consciência de que o Movimento Indígena somente pode ser bem-sucedido se se constituir politicamente, se se dinamizar em termos público-políticos, vinculando-se profundamente à sociedade civil e buscando nela hegemonia cultural; (b) em termos de autoafirmação e de autoexpressão identitárias, comunitárias, como singularidade antropológica, passando pelo desvelamento, pela denúncia e pela publicização da violência sofrida e vivida, da negação, da exclusão e da marginalização que sofreram ontem e que vivem hoje, e chegando-se à crítica do presente como núcleo político, normativo e cultural desse mesmo Movimento Indígena; e (c) a constituição de uma voz-práxis que se processa, se dinamiza e se manifesta pública e politicamente em termos de eu-nós lírico-político ativista e militante. Aqui, portanto, está o núcleo estilístico, epistemológico e político do Movimento Indígena de um modo geral e, para nosso caso nesse texto, da literatura indígena brasileira em particular, a saber, uma voz-práxis ativista e militante, marcada por um eu-nós lírico-político que parte da comunidade de origem, publiciza a violência e a marginalização sofridas e vividas, assumindo uma postura ativista e militante sob a forma de crítica do presente. No que se segue, gostaríamos, a partir da análise de textos literários de autores/as indígenas brasileiros/as, de provar e de desenvolver nosso argumento.

Primeiramente, o ponto de partida das produções estético-literárias indígenas, em termos de voz-práxis militante e ativista, está na afirmação e na utilização da tradição e da pertença comunitárias como base, mote e condição para a autoexpressão e a autoafirmação do eu-nós lírico-político e, a partir daqui, 
sob a forma de ativismo e de militância, de crítica do presente. Como dissemos anteriormente, sem essa pertença à e essa utilização da tradição comunitária, sem essa consciência e essa valorização de sua singularidade antropológica simplesmente não existiria literatura indígena - assim como, evidentemente, não existiria literatura de minorias. Isso porque o/a escritor/a indígena (como de resto o/a escritor/a pertencente às minorias) não é uma mônada, que não apenas vive isolada da coletividade, senão que também se constitui de modo auto-subsistente e autossuficiente e se dinamiza de maneira autorreferencial, tornando-se como que sobreposta e independente em relação ao contexto de que emerge, ao qual está inserida e faz parte. No caso da voz-práxis estético-literária indígena, sob a forma de um eu-nós lírico-político ativista e militante e em termos de crítica do presente, a afirmação e a utilização do arcabouço antropológico-ontológico, sociocultural e epistemológico-político comunitário, de suas formas de ser e de estar no mundo, suas práticas, seus valores e suas experiências, embasam e dinamizam a própria construção e a própria vinculação público-política da obra-práxis, definindo mesmo o seu sentido como crítica do presente a partir da denúncia, do desvelamento e da crítica à exclusão, à marginalização e à violência vividas e sofridas. Com isso, se a voz-práxis estético-literária indígena é crítica do presente, assumindo-se diretamente sob a forma de um eu-nós lírico-político que é ativista e militante, ela assim o é, assim se constitui e assim se dinamiza por causa da pertença comunitária, por meio da afirmação e da utilização da tradição ancestral como arcabouço normativo da manifestação público-política enquanto diferença. O caso do xamã yanomami Davi Kopenawa pode servir-nos de exemplo no que diz respeito a esse argumento.

Eu não tenho velhos livros como eles, nos quais estão desenhadas as histórias dos meus antepassados. As palavras dos xapiri estão gravadas no meu pensamento, no mais fundo de mim. São as palavras de Omama. São muito antigas, mas os xamãs as renovam o tempo todo. Desde sempre, elas vêm protegendo a floresta e seus habitantes. Agora é minha vez de possuí-las. Mais tarde, elas entrarão na mente de meus filhos e genros e, depois, na dos filhos e genros deles. Então será a vez deles de fazê-las novas. Isso vai continuar pelos tempos afora, para sempre. Dessa forma, elas jamais desaparecerão. Ficarão sempre no nosso pensamento, mesmo que os brancos joguem fora as peles de papel deste livro em que elas estão agora desenhadas; mesmo que os missionários, que nós chamamos "gente de Teosi", não parem de dizer que são mentiras. Não poderão ser destruídas pela água ou pelo fogo. Não envelhecerão como as que ficam coladas em peles de imagens, tiradas de árvores mortas. Muito tempo depois de eu já ter deixado de existir, elas continuarão tão novas e fortes como agora. São essas palavras que pedi para você fixar nesse papel, para dá-las aos brancos que quiserem conhecer seu desenho. 
DANNER, L. F;

DORRICO, J.;

DANNER, F.

A estilística

da literatura indigena

brasileira: $a$

alteridade

como crítica do

presente - sobre a

noção de eu-nós

lírico-político
Quem sabe assim eles finalmente darão ouvidos ao que dizem os habitantes da floresta e começarão a pensar com mais retidão a seu respeito? (KOPENAWA; ALBERT, 2015, pp. 65-66).

Note-se três aspectos fundamentais dessa passagem acima, d'A queda do céu: palavras de um xamã yanomami, a saber: a utilização da tradição ancestral e comunitária, nesse caso do xamanismo, como base da significação, da autoexpressão e da autoafirmação, como fundamento da práxis ativista e militante do eu-nós lírico-político; a profunda pertença e dependência à comunidade de origem e, assim, a fala-práxis do/a escritor/a como comunidade, como minoria, em nome dela e desde ela; e a crítica do presente sob a forma de denúncia da marginalização e a consequente tentativa de um diálogo-práxis paritário, entre alteridades que fazem parte de um todo comum, social, cultural, político, institucional, ecológico e mesmo econômico. O que se percebe nesses três pontos, portanto, como horizonte deles, é exatamente o sentido político-politizante, carnal e vinculado do eu-nós lírico-político constituído, dinamizado e assumido pela literatura indígena brasileira em particular e pela literatura de minorias de um modo geral, um sentido político-politizante, carnal e vinculado em termos de pertença, autoexpressão e autoafirmação comunitárias, como grupo, como minoria. Aqui, a construção da obra, a voz-práxis público-política e a crítica do presente se fundam e se realizam por causa da tradição ancestral e da ligação com a comunidade de origem, para além de qualquer neutralidade, objetividade, formalismo, impessoalidade e imparcialidade metodológico-axiológicas. Dito de outro modo: é por constituir-se como minoria e falando desde ela e por ela que Davi Kopenawa pode tanto superar seu silenciamento quanto denunciar e resistir contra a exclusão, a marginalização e a violência sofridas e vividas. Como dissemos acima, sem esse arcabouço fornecido pela tradição ancestral e sem essa vinculação à comunidade de origem, como minoria, não haveria qualquer condição de sentido, qualquer fundamentação e, portanto, qualquer voz-práxis ativista e militante, crítica do presente dos indígenas por si mesmos, das minorias e por parte delas. Por isso, no que se refere ao estilo, à dinâmica e ao escopo da voz-práxis estético-literária indígena, podemos traçar sua manifestação em termos de um eu-nós lírico-político que parte da e afirma a sua tradição ancestral como condição da expressão e do sentido; desvela, publiciza e critica as situações de marginalização e de violência, de modo a entabular uma crítica do presente que se escora na e se dinamiza por meio da afirmação e da utilização dessa tradição ancestral; e, com isso, torna-se diretamente ativismo e militância estético-políticos. É Davi Kopenawa que fala novamente a nós acerca disso:

Apesar de tudo isso, os brancos já nos ameaçaram muitas vezes para nos obrigar a abandonar os xapiri. Nessas ocasiões, só sabiam dizer: "Seus espíritos estão mentindo! São fracos e estão enganando vocês! São de Satanás!". No começo, quando eu ainda era muito jovem, tinha medo da fala desses forasteiros e, por causa delas, cheguei a duvidar dos
Revista Letras,

Curitiba, UFPR,

n. 97 , pp. 143-166,

jan./jun. 2018.

ISSN 2236-0999

(versão eletrônica) 
xapiri. Por algum tempo, me deixei enganar por essas más palavras e até tentei, com muito esforço, responder às palavras de Teosi. Mas isso acabou mesmo! Faz muito tempo que eu não deixo mais as mentiras dos brancos me confundirem e que não me pergunto mais: "Por que eu não tento virar um deles?”. Tornei-me homem, meus filhos cresceram e tiveram seus próprios filhos. Agora, nunca mais quero ouvir más palavras sobre os xapiri! Omama os criou depois de ter desenhado nossa floresta e, desde então, eles continuaram cuidando de nós. Eles são muito valentes e muito bonitos. Seus cantos fazem nosso pensamento aumentar em todas as direções e ficar firmes. E por isso vamos continuar fazendo dançar suas imagens e defendendo suas casas, enquanto estivermos vivos. Somos habitantes da floresta. É o nosso modo de ser e são estas palavras que quero fazer os brancos entenderem (KOPENAWA; ALBERT, 2015, p. 511).

A pertença comunitária enquanto singularidade antropológica e a afirmação e a utilização da tradição ancestral e xamânica como fundamento da significação, como base da constituição e da dinamização da voz-práxis enquanto crítica do presente, por conseguinte, especificam, caracterizam e definem o sentido daliteratura indígena brasileira produzida desde os anos 80 e 90 do século passado, situação que, como mencionamos en passant acima, ocorreu no contexto da emergência, da consolidação e do fortalecimento público-político do Movimento Indígena enquanto organização dos povos indígenas, reação política, cultural e epistêmica contra o silenciamento, a exclusão, a marginalização e a violência vividas e sofridas, reação política, cultural e epistêmica contra a invisibilização público-política do/a indígena. É nesse sentido que estamos falando, nesse texto, do caráter político-politizante, carnal e vinculado das minorias de um modo geral e dos povos indígenas em particular, de sua voz-práxis estética, literária e política, ou seja, enquanto minorias, sua atuação público-política, que rompe com o silenciamento, a invisibilização e a privatização a que foram e são submetidos, imbrica profundamente indivíduo e comunidade, autor/a e grupo, tradição e crítica do presente. No caso da produção estético-literária indígena e sob a forma de consolidação de um amplo espectro de escritores/as indígenas, temos a profunda ligação com e a vinculação e a dependência ao Movimento Indígena como o cerne dessa mesma produção estético-literária e dessa mesma atuação público-política como escritores/as, o que corrobora nosso argumento de que a voz-práxis estético-literária indígena como crítica do presente, como ativismo e militância políticos e politizantes, carnais e vinculados, se enraíza profundamente e se baseia diretamente na tradição ancestral e na pertença e na tradição comunitárias, inclusive em termos da negação, da marginalização e da violência vividas e sofridas como minorias, para constituir-se e dinamizar-se como ativismo e militância em prol do movimento indígena, como movimento indígena, em verdade. Essa, de todo modo, é a percepção de Daniel Munduruku no que diz respeito à emergência e à publicização da literatura indígena desde a década de 1990. 
DANNER, L. F;

DORRICO, J.;

DANNER, F.

A estilística

da literatura indígena

brasileira: $a$

alteridade

como crítica do

presente - sobre a

noção de eu-nós

lírico-político
Nesse sentido, o momento histórico da literatura nativa brasileira se confunde com o surgimento do movimento político que mobilizou mentes e corações em torno da sobrevivência física e espiritual de nossa gente. Foi, no entanto, na década de 1990 que ela ganhou as dimensões que hoje ocupa no cenário literário nacional. Foi nessa década que autores individuais começaram a surgir, recebendo algum destaque nas mídias. Esse foi o surgimento de um movimento que tem crescido a cada ano, a tal ponto de haver interesse crescente por parte das universidades em estudar o fenômeno. [...] Há entidades indígenas preocupadas em utilizar a escrita como uma arma capaz de reverter situações de conflito, denunciar abusos internos e externos, mostrando que a literatura - seja ela entendida como se achar melhor - é verdadeiramente um novo instrumental utilizado pela cultura para atualizar a Memória ancestral (MUNDURUKU, 2017, pp. 122-123).

Nessa reflexão de Daniel Munduruku, nós podemos perceber a correlação de três ideias fundamentais que, como estamos argumentando, constituem de modo nucelar à literatura indígena em particular e à literatura de minorias de um modo geral, a saber: (a) literatura indígena e movimento político indígena; (b) autoafirmação e autoexpressão identitárias, comunitárias, xamânicas, via voz-práxis estético-literária, com resistência cultural e luta política, crítica do presente como denúncia da marginalização e da violência vividas e sofridas; e (c) literatura, atualização cultural e valorização da memória-pertença comunitária. Note-se esse aspecto fundante da correlação de literatura indígena e de Movimento Indígena, que consiste na atualização da memória, memória esta entendida em um sentido amplo: por um lado, a memória como reconstrução simbólico-antropológica da sabedoria ancestral, com a afirmação dos principais traços culturais e axiológicos próprios a cada comunidade indígena (e, depois, próprios ao Movimento Indígena como um todo), o que leva à utilização desse arcabouço normativo como núcleo fundante da constituição e da atuação dos/as indígenas em termos público-políticos; por outro, a memória da própria dor, da negação, da exclusão e da violência sofridas e vividas, que se constitui no verdadeiro aguilhão da crítica social, da resistência cultural e do ativismo e da militância políticos. Retomar e atualizar a memória, nesse sentido, enquanto tarefa fundamental assumida tanto pela literatura indígena em particular quanto, de um modo mais geral, pelo próprio Movimento Indígena, é o caminho por excelência não só para a crítica do presente, para esse ativismo e essa militância políticos que definimos como o cerne da voz-práxis estético-literária indígena sob a forma de um eu-nós lírico-político vinculado, carnal e politizante, mas também para evitar-se o silenciamento, a desagregação e até o apagamento dos próprios povos indígenas que, enquanto minorias, sofrem um processo avassalador de deslegitimação e de destruição. Por isso, a memória, enquanto pertença e vinculação sociocultural e enquanto rememoração-lembrança da dor, da marginalização, da exclusão e da violência sofridas e vividas, está no
Revista Letras, Curitiba, UfPR, n. 97 , pp. 143-166, jan./jun. 2018. ISSN 2236-0999 (versão eletrônica) 
âmago das produções estético-literárias indígenas e embasam e orientam o eu-nós lírico-político em termos de constituição e de dinamização de uma voz-práxis ativista e militante, política e politizante, carnal e vinculada, e sob a forma de crítica do presente. É o que podemos perceber, por exemplo, na poesia de Eliane Potiguara:

Nosso ancestral dizia: Temos vida longa!/Mas caio da vida e da morte/E range o armamento contra nós./Mas enquanto eu tiver o coração aceso/Não morre a indígena em mim/ E nem tampouco o compromisso que assumi/Perante os mortos/De caminhar com minha gente passo a passo/E firme, em direção ao sol./Sou uma agulha que ferve no meio do palheiro/Carrego o peso da família espoliada/Desacreditada, humilhada/Sem forma, sem brilho, sem fama (POTIGUARA, 2004, pp. 102-103).

Háum trânsito e umaligação diretos, nessa passagem, em termos estético-literários e epistemológico-políticos, entre a tradição ancestral e comunitária, o desvelamento, a explicitação e a publicização da violência vivida e sofrida e/como crítica do presente, a resistência cultural e a luta política. Ora, nessa passagem também podemos perceber a vinculação umbilical da autora com seu povo, com o passado, o presente e o destino de seu povo, o que demonstra e enfatiza o caráter umbilical entre o indivíduo que escreve-age e a comunidade da qual ele faz parte, à qual aquele/a pertence. Nesse sentido, é somente sob a forma de ativismo e de militância que a memória - naquele duplo sentido por nós definido acima, tradição cultural-comunitária e rememoração-publicização da violência vivida e 160 sofrida - que a voz-práxis estético-literária indígena se constitui e se dinamiza, de modo que o eu-nós lírico-político encontra nessa vinculação comunitária e nessa politização radical o seu sentido, o seu mote, o seu estilo e a sua dinâmica, podendo e devendo ser lido como práxis político-normativa radical, de modo que a produção do/a autor/a e o sentido e a vinculação da obra são e se dão em primeira mão, conforme estamos argumentando, como ativismo e militância, como associação ao Movimento Indígena de onde emergem e ao qual retornam, promovem, publicizam. Somente mantendo-se atenção a esse Movimento Indígena, como organização político-cultural dos povos indígenas, sob a forma de autoexpressão e autoafirmação e, a partir daqui, de crítica do presente, que conseguimos compreender e, nesse caso, valorizar essa mesma literatura indígena como ativismo e militância do eu-nós lírico-político, porque, no fim das contas, a literatura indígena não apenas não é autônoma e nem sobreposta em relação à odisseia indígena, à vinculação, à história, ao presente e ao futuro dos/as indígenas, senão que está totalmente dependente e devotada à promoção e ao fortalecimento público-político do Movimento Indígena. Aliás, nesse aspecto, para que a literatura indígena tenha um futuro, o indígena deve ter um futuro, deve não apenas sobreviver ao permanente etnocídio-genocídio simbólico-material (que lhe confere, no máximo, um papel periférico e o estigma de pária), mas também garantir que as tradições, os valores, as práticas, os ritos, as línguas e a memória indígena vivifiquem entre os povos indígenas e na esfera público-política, junto aos não-índios. De todo modo, como se pode perceber aqui, a literatura indígena 
DANNER, L. F.;

DORRICO, J.;

DANNER, F.

A estilística

da literatura indígena

brasileira: a alteridade como crítica do presente - sobre a noção de eu-nós lírico-político está direta e profundamente alinhada ao Movimento Indígena exatamente porque, se não existirem mais índios/as, não existirá mais literatura indígena, mas apenas literatura sobre indígenas, o que implica nessa dupla tarefa, por parte dos povos indígenas, de seus/ as escritores/as e intelectuais: a de afirmação de sua própria tradição entre seus membros, em suas comunidades; e a de publicização e politização dessa sua tradição e da violência vivida e sofrida. Em ambos os casos, que de todo modo são interligados, a literatura indígena é uma espécie de propedêutica ao Movimento Indígena, um manifesto em prol deste, como podemos perceber no trabalho de Márcia Kambeba:

Nós, povos indígenas,

Habitantes do solo sagrado,

Mesmo sem nossa aldeia,

Somos herdeiros de um passado.

Buscamos manter a cultura,

Vivendo com dignidade,

Exigimos nosso respeito,

Mesmo vivendo na cidade.

Somos parte de uma história,

Temos uma missão a cumprir,

De garantir aos tanu muariry,

Sua memória, seu porvir.

Vivendo na rytama do branco,

Minha Uka se modificou,

Mas a nossa luta pelo respeito,

Essa ainda não terminou.

Pela defesa do que é nosso,

Todos os povos devem se unir,

Relembrando a bravura

Dos Kambeba, dos Macuxi,

Dos Tembé e dos Kocama,

Dos valentes Tupi-Guarani.

Assim, os povos da Amazônia,

Em uma grande celebração,

Dançam o orgulho de serem,

Representantes de uma nação,

Com seu canto vêm dizer:

Formamos uma aldeia de irmãos

(KAMBEBA, 2013, p. 35).
Revista Letras, Curitiba, UfPR, n. 97 , pp. 143-166, jan./jun. 2018. ISSN 2236-0999 (versão eletrônica) 
OMovimento Indígena, como argumenta mos aolongo deste segundo capítulo, serve de contexto, de base e de mote para a constituição epistemológico-política da literatura indígena, definindo sua estilística como ativismo, militância e engajamento público-políticos marcados pela defesa da causa indígena, que passam pela afirmação e pela atualização da memória ancestral e comunitária, se transformam em denúncia da violência vivida e sofrida como minoria e chegam à crítica do presente, sob a forma de uma voz-práxis política-politizante, carnal e vinculada. Nesse quesito, a literatura indígena se dirige tanto aos próprios povos indígenas, no intuito de contribuir para a reafirmação e a valorização de sua constituição antropológica, de sua tradição cultural, dos valores, das práticas e dos ritos que lhe constituem em seu âmago, quanto aos não-indígenas, com o objetivo, aqui, seja de publicizar a causa indígena, a dor, a marginalização e a violência pela qual passaram e passam, seja também para sensibilizar, para dar-se a conhecer, para contribuir, como alteridade, na formação de uma cultura nacional mais plural, respeitosa e acolhedora das diferenças. Essa é, para Daniel Munduruku, uma das grandes intenções da literatura indígena, a saber, contribuir na formação de uma cultura democrática e de uma perspectiva moral pluralistas, valorizadoras, acolhedoras e promotoras das diferenças. Com efeito, nesse caso, a formação de uma cultura e de uma consciência moral democráticas, marcadas pelo pluralismo e pela diversidade, passa por essa militância e por esse ativismo que estamos atribuindo como eixo da constituição e da dinamização da literatura indígena enquanto eu-nós lírico-político, isto é, não se pode educar para a democracia, para o pluralismo e para as diferenças sem a participação e o contato com essas mesmas diferenças, posto que é somente por meio da interação entre diferentes que se dão os choques, as oposições, mas também as sínteses, o reconhecimento. As diferenças, por conseguinte, são o núcleo da democracia, da educação democrática, de uma cultura público-política democrática que é aberta, pluralista e participativa. Por isso, como dissemos, a literatura indígena brasileira, na contemporaneidade, torna-se o aguilhão político-politizante que, na correlação de memória ancestral-comunitária e de crítica do presente, tanto serve de suporte ao Movimento Indígena quanto se enraíza na esfera público-política em termos de ativismo, de militância e de engajamento, buscando contribuir no amadurecimento da democracia, na construção de uma cultura público-política e de uma educação democráticas que tenham nas diferenças, nas minorias seu núcleo normativo, seu norte, sua práxis.

A tarefa que nos propomos é reeducar as novas gerações de brasileiros para que consigam nos olhar com a dignidade que merecemos. Para isso, não podemos fazer um enfrentamento violento como nos tempos antigos, mas usar das mesmas ferramentas que foram utilizadas para estabelecer seu preconceito: a escrita e a literatura. Por meio delas, inventaram rivalidades, difundiram os estereótipos e os preconceitos e, principalmente, dividiram-nos para poderem dominar nossos saberes ancestrais (Munduruku, 2016, pp. 191-192). 
DANNER, L. F;

DORRICO, J.;

DANNER, F.

A estilística

da literatura indígena

brasileira: $a$

alteridade

como crítica do

presente - sobre a

noção de eu-nós

lírico-político

Como salienta Axel Honneth, o reconhecimento é ontogeneticamente anterior ao conhecimento, ou seja, a perspectiva simbólico-normativa define o tipo de enquadramento que será dado aos semelhantes e, principalmente, às alteridades, às diferenças. Isto é, o modo como conhecemos e enquadramos os outros é caudatário do e determinado pelo tipo de formação simbólica, moral e normativa que temos, de modo que a nossa régua para medir e enquadrar o mundo e os nossos óculos para vermos aos outros dependem da e se fundam na forma de socialização e de educação moral que temos e que recebemos (cf.: Honneth, 2007). Ora, o que Daniel Munduruku está querendo significar, com a passagem acima, está em que a violência contra os/as indígenas foi e é, em primeiro e fundamental lugar, uma violência simbólica, normativa, moral, política; e só depois ela se transforma em destruição material, em etnocídio-genocídio. Desse modo, a própria transformação dessa situação é, como condição de tudo o mais, uma socialização democrática e uma reeducação moral, uma reconfiguração do imaginário e do simbolismo em torno às diferenças, em torno às alteridades, em torno aos/às indígenas. É também com essa socialização equitativa e com essa educação democrática aberta, plural e inclusiva que a literatura indígena se compromete e às quais ela se dirige.

\section{Considerações finais}

Ao longo do texto, procuramos desenvolver a ideia de que a estilística definidora da literatura indígena (estendendo-a também à literatura de minorias) consiste em uma voz-práxis estético-literária marcada por e afirmadora de um eu-nós lírico-político

Revista Letras, militante e ativista, que se constitui e se dinamiza a partir de três atitudes e de três momentos imbricados e mutuamente dependentes: a afirmação da memória ancestral e comunitária, que possibilita a autoexpressão desde a própria singularidade antropológica; a rememoração, a explicitação e a publicização da marginalização, da exclusão e da violência vividas e sofridas enquanto minoria, que leva à crítica do presente, à resistência cultural e à luta política; e a constituição dessa voz-práxis política-politizante, carnal e vinculada, que se dinamiza como ativismo e militância, demarcando o sentido da autoria e da obra como pertença comunitária-grupal, como publicização e politização da violência sofrida como minoria, como desvelamento da condição política da minoria e, assim, como ativismo e militância cotidianos em termos de crítica do presente. Em nossa percepção, é esse o núcleo duro da literatura de minorias de um modo geral e, como procuramos mostrar na segunda parte desse texto, da literatura indígena brasileira em particular. Esse núcleo imbrica, direta e intrinsecamente, eu e comunidade, indígena e Movimento Indígena, permitindo a retomada, a afirmação e a promoção da memória no duplo sentido do termo, como valorização da tradição ancestral-comunitária e como crítica publicizada e politizante da violência vivida e sofrida como minoria.

Nesse sentido, retomando a passagem de Ailton Krenak no início desse texto, o verdadeiro descobrimento do Brasil é esse realizado e assumido pelo Movimento Indígena de um modo geral e pela literatura indígena brasileira contemporânea em

Curitiba, UFPR,

n. 97 , pp. 143-166,

jan./jun. 2018.

ISSN 2236-0999

(versão eletrônica) 
particular desde a década de 1980 para cá, que exige exatamente esse ativismo, essa militância e esse engajamento em termos público-políticos da voz-práxis indígena sob a forma de um eu-nós lírico-político vinculado, politizante e carnal. O trabalho está por fazer e, em verdade, consiste em uma luta permanente na esfera público-política e como práxis político-normativa pungente, uma luta que trabalha nessa correlação de retomada da memória e de crítica do presente como o eixo estruturante da atuação do Movimento Indígena coletivamente e nas figuras de seus/as intelectuais. É necessário que os povos indígenas e seus/as intelectuais adentrem em cheio na esfera público-política e em termos desse ativismo, dessa militância e desse engajamento, pois a autoafirmação e a autoexpressão como singularidade antropológica e, a partir disso, sua crítica do presente não apenas não são um fim em si, senão que também não são suficientes para o sucesso do Movimento Indígena. Também é imprescindível, nessa caminhada, a construção de hegemonia cultural, política e normativa, que somente pode ser dada, edificada e viabilizada por meio do ativismo, da militância e do engajamento, por meio do Movimento Indígena e, no caso, da literatura indígena na e como esfera público-política, como práxis político-normativa radical. Lembrando que o mesmo vale para as minorias em geral, como sua sina, seu destino, se quiserem sobreviver e frutificar para si e socialmente. 
DANNER, L. F;

DORRICO, J.;

DANNER, F.

A estilística

da literatura indígena

brasileira: a

alteridade

como crítica do

presente - sobre a

noção de eu-nós

lírico-político

\section{Referências}

ALMEIDA, Maria Inês de. Desocidentada: experiência literária em terra indígena. Belo Horizonte: Editora UFMG, 2009.

ALMEIDA, Maria Inês de; QUEIROZ, Sônia. Na captura da voz: as edições da narrativa oral no Brasil. Belo Horizonte: Autêntica, 2004.

BANIWA, Gersem dos Santos Luciano. O índio brasileiro: o que você precisa saber sobre os povos indígenas no Brasil de hoje. Brasília: Ministério da Educação, Secretaria de Educação Continuada, Alfabetização e Diversidade; LACED/Museu Nacional, 2006.

BUTLER, Judith. Problemas de gênero: feminismo e subversão da identidade. Rio de Janeiro: Civilização Brasileira, 2003.

DALCASTAGNĖ, Regina. Literatura brasileira contemporânea: um território contestado. Vinhedo: Editora Horizonte, 2012.

DANNER, Leno Francisco; DORRICO PERES, Julie. “A literatura indígena como crítica da modernidade: sobre xamanismo, normatividade e universalismo - notas desde 'A queda do céu: palavras de um xamã yanomami', de Davi Kopenawa e Bruce Albert, O Eixo e a Roda (UFMG), v. 26, n. 03, 2017, pp. 129-156.

DANNER, Leno Francisco; BAVARESCO, Agemir; DANNER, Fernando. "A estética das minorias contra a correlação de institucionalismo forte, cientificismo e tecnicalidade: sobre a voz-práxis das minorias como arte-literatura”, Clareira Revista de Filosofia da Região Amazônica, v. 4, n. 1, 2017, pp. 15-48.

DORRICO, Julie. "A mídia e a literatura como ferramentas de autoafirmação e de re-existência dos povos indígenas na contemporaneidade", pp. 65-92. In: CEI, Vitor; DANNER, Leno Francisco; OLIVEIRA, Marcus Vinícius Xavier de; BORGES, Davi G. (Orgs). O que resta das jornadas de junho. Porto Alegre: Editora Fi, 2017.

FANON, Franz. Os condenados da Terra. Rio de Janeiro: Civilização Brasileira, 1968.

FREIRE, Paulo. Pedagogia do oprimido. Rio de Janeiro: Paz e Terra, 1987.

GRAÚNA, Graça. Contrapontos de literatura indígena contemporânea no Brasil. Belo Horizonte: Mazza Edições, 2013.

HABERMAS, Jürgen. A inclusão do outro: estudos de teoria política. São Paulo: Loyola, 2002.

HABERMAS, Jürgen. Teoría y práxis: estudios de filosofía social. Madrid: Editorial Tecnos, 1987

HONNETH, Axel. Reificación: un estudio en la teoría del reconocimiento. Buenos Aires: Katz, 2007.

KAMBEBA, Márcia Wayna. Poemas e crônicas. Manaus: Grafisa Gráfica e Editora, 2013.
Revista Letras, Curitiba, UFPR, n. 97 , pp. 143-166, jan./jun. 2018. ISSN 2236-0999 (versão eletrônica) 
KOPENAWA, Davi; ALBERT, Bruce. A queda do céu: palavras de um xamã yanomami. São Paulo: Companhia das Letras, 2015.

KRENAK, Ailton. Encontros. Rio de Janeiro: Azougue, 2015.

MARX, Karl. A questão judaica. Lisboa: FCG, 1989.

MARX, Karl; ENGELS, Friedrich. A ideologia alemã. São Paulo: Martins Fontes, 2001.

MUNDURUKU, Daniel. Memórias de indio: uma quase autobiografia. Porto Alegre: Edelbra, 2016.

MUNDURUKU, Daniel. Mundurukando II: roda de conversa com educadores. Lorena: UK’A Editorial, 2017.

MUNDURUKU, Daniel. "Visões de ontem, hoje e amanhã: é hora de ler as palavras", p. 15-16. In: POTIGUARA, Eliane. Metade cara, metade máscara. São Paulo: Global, 2004.

POTIGUARA, Eliane. Metade cara, metade máscara. São Paulo: Global, 2004.

SPIVAK, Gayatri C. Pode o Subalterno Falar? Belo Horizonte: Editora da UFMG, 2010.

THIÉL, Janice. Pele silenciosa, pele sonora: a literatura indígena brasileira em destaque. Belo Horizonte: Autêntica Editora, 2012.

WERÁ, Kaká. O trovão e o vento: um caminho de evolução pelo xamanismo tupi-guarani. São Paulo: Polar, 2016.

Submetido em: 05/12/2017

Aceito em: 16/05/2018 